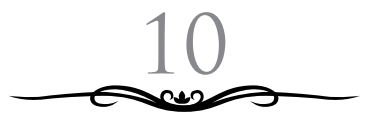

\title{
PENGGUNAAN APLIKASI E-PRINTS UNTUK PENGEMBANGAN INTITUTIONAL REPOSITORY DAN PENGARUHNYA TERHADAP PERINGKAT WEBOMETRICS PERGURUAN TINGGI DI INDONESIA
}

\author{
Ummi Rodliyah \\ UIN Sunan Ampel Surabaya, Jawa Timur, Indonesia \\ umir06@yahoo.co.uk
}

\begin{abstract}
This article deals with the use of E-prints application to develop institutional repository and its influence on webometrics rank of universities in Indonesia. One of the indicators of success in the strategy of developing institutional repository in university libraries can be seen from its webometricsrank. Assessment in determining the rank of webometrics repository is based on some criteria, such as the level of visibility which is influenced by the software used. Based on this research, more than 50\% of institutional repository in Indonesia use E-prints application, whileDspace is the second most used application in Indonesia. Even though Ganesha Digital Library (GDL) is created as national product, the users no longer use or even leave it for not being refined simultaneously by its developer. Some universities which used to apply GDL have immigrated to Eprints application, such as UIN SunanAmpel Surabaya and UIN SunanKalijaga Yogyakarta.
\end{abstract}

Keywords: Institutional, Repository, Libraries. 


\begin{abstract}
Abstrak
Perpustakaan perguruan tinggi di Indonesia dapat dilihat dari posisi dan peringkatnya dalam webometric. Penilaian dalam menentukan peringkat repository webometrics ini didasarkan pada beberapa kriteria, di anataranya adalah tingkat visibility yang dipengaruhi oleh software yang digunakan. Berdasarkan penelitian ini, lebihdari $50 \%$ institutional repository di Indonesia menggunakan aplikasi Eprints. Sementara Dspace merupakan aplikasi terbanyak kedua yang digunakan di Indonesia.GDL (Ganesha Digital Library) meskipun sebuah aplikasi karya anak bangsa, namun telah banyak ditinggalkan oleh penggunanya karena tidak dikembangkan secara berkesinambungan oleh developpernya. Beberapa perguruan tinggi yang semula menggunakan GDL, telah bermigrasi keaplikasi Eprints termasuk UIN SunanAmpel Surabaya, dan UIN Sunan Kalijaga Yogyakarta.
\end{abstract}

Kata Kunci: Institusional, repository, Perpustakaan.

\title{
A. Pendahuluan
}

Era informasi digital mengharuskan perpustakaan menyesuaikan diri dengan perkembangan teknologi dalam strategi pengembangannya. Demikianjuga dengan perpustakaan perguruan tinggi yang dituntut menyediakan akses yang luas terhadap sumber-sumber informasi digital untuk mendukung pelaksanaan pendidikan dan pengajaran, penelitian dan pengabdian kepada masyarakat. Perpustakaan universitas harus mampu menjadi mediator yang mengantarkan sifitas akademika melaksanakan tugas-tugas dalam tridharma perguruan tinggi. Pengembangan jenis layanan perpustakaan harus mempertimbangakan aspek kekinian dan kemudahan akses bagi pemustaka sehingga tingkat kemanfaatannya dapat dimaksimalkan.

Dalam beberapa tahun terakhir, banyak perpustakaan peguruan tinggi di Indonesia yang mencurahkan perhatiannya pada pengembangan Institutional Repository (IR). IR yang merupakan kekayaan ilmiah universitas berciri khas lembaga merupakan online resourches yang luar biasa manfaatnya bagi pengembangan 
keilmuan jika dikelola dengan baik. Fenomena Open Access Initiative (OAI) menjadi dasar dan alasan untuk pengembangan Online Repository. Semangat untuk berbagi sumber informasi menjadi semakin tampak dengan menjamurnya koleksi digital IR secara online. Kemanfaatan itu tidak hanya bagi sifitas akademika lembaga yang bersangkutan namun menjadi lebih luas karena dapat diakses oleh siapa saja melalui jaringan internet global.

Berbagai aplikasi perangkat lunak dikembangkan dan dimanfaatkan untuk mengelola repository, baik yang berbayar maupun opensource, berbasis web dengan berbagai aplikasi pendukung yang compatible untuk berbagai konten atau objek digital. Aplikasi-aplikasi tersebut dikembangkan untuk memenuhi kebutuhan dalam penyimpanan objek digital dan metadata serta untuk mendukung berbagai layanan yang lebih luas dalam sebuah intitusi atau lembaga. Perpustakaan perguruan tinggi di Indonesia menggunakan aplikasi yang berbeda untuk mengelola repository. Ada eprints, dspace, GDL, SLiMS dan sebagaian institusi menggembangkan aplikasi sendiri untuk repositorynya. Namun dalam beberapa tahun terakhir terdapat kecenderungan perpustakaan perguruan tinggi untuk menggunakan salah satu aplikasi opensource yaitu eprints. Beberapa perpustakaan perguruan tinggi yang semula menggunakan aplikasi Ganesha Digital Library (GDL) versi 4.2 beralih ke eprints, seperti Perpustakaan UIN Sunan Kalijaga Yogyakarta, dan Perpustakaan UIN Sunan Ampel Surabaya. Fenomena tersebut menimbulkan berbagai pertanyaan bagi penulis yaitu: apa yang melatar belakangi keputusan menggunakan software ini dan adakah pengaruhnya terhadap capaian peringkat repository webometrics. Kedua pertanyaan tersebut menjadi dasar pemikiran tulisan ini yang diharapkan dapat menjelaskan kelebihan dan keunggulan eprints dibandingkan dengan aplikasi lainnya.

\section{B. Pembahasan}

\section{Pengertian Institutional Repository (IR)}

Institutional Repository (IR) banyak dikenal di kalangan pengelola perpustakaan perguruan tinggi sebagai media koleksi 
digital karya universitas yang dilayankan secara online. Institutional Repository (IR) sering juga disebut dengan beberapa istilah lain, di antaranya koleksi seperti skripsi, tesis, dan disertasi sebagai karya ilmiah tugas akhir mahasiswa sering kali disebut juga dengan Gray Literature (literature kelabu) atau sebelumnya juga diklasifikasikan sebagai koleksi lokal konten. Perbeaan antara ketiganya masih menjadi perbincangan terutama dengan pakar ilmu perpustakaan dan informasi sendiri.

Clifford A. Lynch dalam "Institutional Repositories: Essential Infrastructure for Scholarship in the Digital Age" mengungkapkan "a university-based institutional repository is a set of services that a university offers to the members of its community for the management and dissemination of digital materials created by the institution and its community members. It is most essentially an organizational commitment to the stewardship of these digital materials, including long-term preservation where appropriate, as well as organization and access or distribution".

Kata repository (simpanan) sama populernya dengan kata akses, hal tersebut menunjukkan betapa konsep perpustakaan digital merupakan keberlanjutan tradisi yang sudah mengakar dalam kepustakawanan (librarianship) secara universal. Sedangkan istilah Institutional Repository (IR) merujuk ke sebuah kegiatan menghimpun dan melestarikan koleksi digital yang merupakan hasil karya intelektual dari sebuah komunitas tertentu. Penekanan yang diberikan pada konsep "institutional" atau kelembagaan adalah untuk menunjukkan bahwa materi digital yang dihimpun memiliki keterkaitan erat sekali dengan lembaga penciptanya. ${ }^{2}$

Institusional Repository merupakan salah media untuk mempublikasikan secara online karya-karya khas universitas yang dihasilkan oleh siviitas akademika seperti skripsi, tesis, disertasi,

${ }^{1}$ Clifford A. Lynch, "Institutional Repositories: Ess Ential Infrastructure for Scholarship in the Digital Age”, 2013, http://www:arl.org/bm doc/br226ir. pdf, diakses 10 Februari 2016.

2 Putu Laxman Pendit, Perpustakaan Digital dari A sampai Z (Jakarta: Cita Karyakarsa Mandiri, 2008). 
artikel journal, buku karya dosen, prosiding, bahan ajar, dan lainlain. Dengan media ini universitas dapat meningkatkan sitasi dan peringkat webometricsnya karna karya ilmiah mereka dapat diakses dan dimanfaatkan oleh banyak orang. Semakin banyak diakses dan dikutip orang, maka akan semakin meningkatkan visibilitas dari repository dan pada akhirnya berpengaruh terhadap peringkat webometrics.

Website Ranking Repositori Dunia merupakan inisiatif dari Laboratorium Cybermetrics, sebuah kelompok riset milik Consejo Superior de Investigaciones Científicas (CSIC) badan penelitian publik terbesar di Spanyol. CSIC merupakan salah satu organisasi penelitian dasar pertama di Eropa. CSIC mulai konsis pada tahun 2006 dan terdiri dari 126 pusat-pusat dan lembaga yang tersebar di seluruh Spanyol. CSIC melekat pada Departemen Pendidikan dan tujuan utamanya adalah untuk mempromosikan penelitian ilmiah untuk meningkatkan kemajuan tingkat ilmiah dan teknologi dari negara yang akan memberikan kontribusi untuk meningkatkan kesejahteraan warga. CSIC juga berperan penting dalam pembentukan peneliti baru dan teknisi di berbagai aspek ilmu pengetahuan dan teknologi. ${ }^{3}$. Lembaga ini melakukan penilaian terhadap repository yang terdaftar diseluruh dunia berdasarkan tingkat kekayaan file, visibilitas, dan keterbukaan dokumen mereka berdasarkan seberapa banyak diindeks oleh googlescholar. Penelitian ini mengambil sampel dari repository yang terdaftar dalam 60 peringkat teratas di Indonesia dari webometrics ini per Pebruari 2016. Penelitian ini juga bertujuan melihat pengaruh dari aplikasi yang digunakan oleh repository terhadap capaian peringkat webometrics.

\section{Eprints, Dspace, dan Ganesha Digital Library (GDL)}

Eprints, DSpace dan Ganesha Digital Library (GDL) adalah perangkat lunak untuk mengelola koleksi digital yang banyak digunakan oleh perpustakaan perguruan tinggi di Indonesia.

3 http://repositories.webometrics.info/en/About_Us, diakses 14 Februari 2016. 
Berbeda dengan Eprints dan DSpace, keunggulan dari Ganesha Digital Library (GDL) adalah karya anak bangsa yaitu Knowledge Management Research Groups (KMRG) dari Institut Teknologi Bandung (ITB), ${ }^{4}$ sementara Eprints dari England dan DSpace dikembangkan oleh tim/komunitas dari berbagai Negara yang disponsori oleh MIT dan HP. Berikut ini akan dijelaskan gambaran singkat tentang ketiga aplikasi tersebut.

\section{a. Eprints}

Eprints adalah perangkat lunak opensource yang dikembangkan oleh School of Electronics and Computer Science, University of Southampton, England United Kingdom. Versi pertama dari Eprints ini direlease ke publik pada tahun 2000. Eprints sudah terintegrasi dengan metadata, advanced search untuk penelusuran informasi lanjut, dan fitur-fitur lainnya. Eprints merupakan perangkat lunak perpustakaan digital berbasis opensource, yang dapat dimodifkasi dan disesuaikan dengan kebutuhan lokal ${ }^{5}$. Eprint merupakan aplikasi yang berbasis perl dan dapat berjalan di system operasi windows maupun linux. Proses instalasi Eprints membutuhkan software pendukung yang disebut LAMP (Linux, Apache, MySql dan PHP) untuk membuat webhosting dan PHPMYADMIN, software bebas untuk menangani administrasi basisdata MySql sehingga dapa diakses melalui web browser. ${ }^{6}$ Gambar berikut adalah tampilan aplikasi Eprints.

${ }^{4}$ Azizah Laila, “GDL (Ganesha Digital Library Versi 4, 2," azizahlaila45, June 13, 2013, https://azizahlaila45.wordpress.com/2013/06/13/gdl-ganeshadigital-library-versi-42/.

${ }^{5}$ http://eprints.org.

${ }^{6}$ Solihin Arianto, «Modul Instalasi Eprint 3 Pada Ubuntu Matakulian Perpustakaan Digital”, Prodi Ilmu Perpustkaan Fakultas Adab dan Ilmu Budaya UIN Sunan Kalijaga Yogyakarta, 2013. 


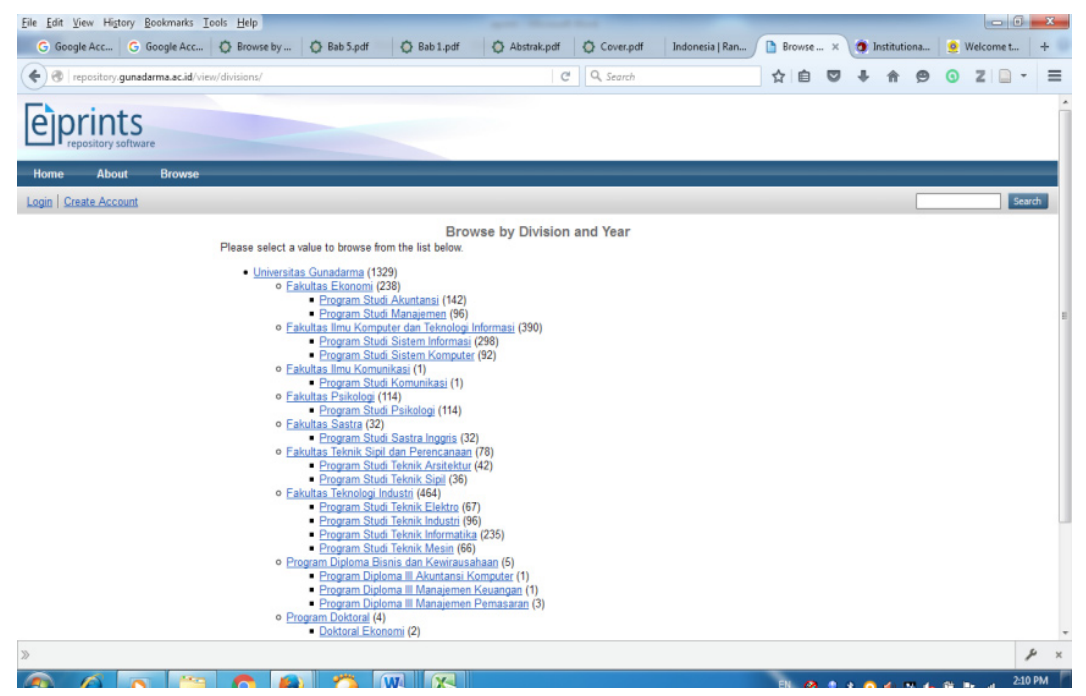

Gambar1. Interface Eprints

Bedasarkan hasil penelitian dari saudara Miftakhul Yazid Fuadi pada tahun 2013 tentang Evaluasi Kualitas Perangkat Lunak Eprints untuk Pengelolaan Perpstakaan Digital di Perpustakaan UIN Sunan Kalijaga Yogyakarta disimpulkan bahwa perangkat lunak eprints sudah memenuhi semua indikator-indikator kualitas perangkat lunak kategori karakteristik operasional perangkat lunak (product operation) dan merupakan software yang mempunyai kualitas cukup baik untuk pengelolaan perpustakaan digital. ${ }^{7}$

\section{b. Ganesha Digital Library (GDL)}

Ganesha Digital Library (GDL Versi 4.2) adalah perangkat lunak untuk pengelolaan perpustakaan digital yang dikembangkan oleh Knowledge Management Research Groups (KMRG) Institut Teknologi Bandung (ITB) (Fuadi, 2013) yang mendapat dukungan dana dari INHERENT DIKTI dengan tujuan mengelola, memanfaatkan dan mendistribusikan koleksi digital. Pada tahun 2006 software GDL dikembangkan lebih lanjut atau up grade dari

${ }^{7}$ Miftakhul Yazid Fuadi, "Evaluasi Kualitas Perangkat Lunak Eprints untuk Pengelolaan Perpustakaan Digital”, 2013, http://digilib.uin-suka. ac.id/9158/2/BAB\%20I,\%20V,\%20DAFTAR\%20PUSTAKA.pdf., diakses 16 Februari 2016. 
GDL 4.0 ke GDL 4.2. Pada GDL 4.2 sudah menggunakan konsep berorientasi pada objek meskipun hanya sebagian. Selain itu, pembagian modul juga sudah dilakukan dengan jelas sehingga hanya dengan melihat struktur modulnya, software ini dapat dipahami dengan cukup mudah. ${ }^{8}$

GDL sempat berkembang sangat popular di kalangan perpustakaan perguruan tinggi sampai terbentuk sebuah jaringan nasional digital library dengan nama IDLN (Indonesian Digital Library Network) yang mempunyai misi mengelola ilmu pengetahuan bangsa Indonesia dengan cara mudah, murah dan untuk semua kalangan, membudayakan tradisi knowledge sharing menuju terciptanya masyarakat madani berbasis ilmu pengetahuan. Namun dalam perkembangannya GDL kemudian mengalami kemunduran dan tidak lagi dikembangkan oleh pengembangnya. Beberapa perpustakaan pengguna GDL mulai mengalami kesulitan untuk mengembangkan aplikasi GDL untuk repositorynya. Beberapa perpustakaan bermigrasi ke aplikasi lain. Hasil evalusi UIN Sunan KaliJaga Yogyakarta tentang GDL menyimpulkan bahwa aplikasi GDL kurang mendukung secara maksimal dalam meningkatkan rangking universitas (webometrics), security dari GDL terhadap file-file yang sudah diunggah kurang baik, ${ }^{9}$ dan sudah tidak dikembangkan lagi oleh developer-nya. UIN Sunan Kali Jaga Yogyakarta melakukan migrasi dari GDL versi 4.2 ke Eprints pada Mei 2012 dengan pertimbangan Eprints memiliki security yang lebih baik dan dapat di-index oleh google. Beberapa perpustakaan perguruan tinggi selain UIN Sunan Kalijaga juga melakukan migrasi dari GDL ke Eprints, di antara nya adalah Perpustakaan UIN Sunan Ampel Surabaya, dan Institut Teknologi Sepuluh Nopember Surabaya (ITS).

${ }^{8}$ Azizahlaila, “GDL (Ganesha Digital Library) Versi 4.2”, azizahlaila45, June 13, 2013, https://azizahlaila45.wordpress.com/2013/06/13/gdl-ganeshadigital-library-versi-42/., diakses 11 Februari 2016.

9 Nur Hasan, "Strategi Membangun dan Mengelola Institutional Repository pada Lingkup Perguruan Tinggi”, Makalah Konferensi Perpustakaan Digital Indonesia ke-3 di Bandung, 2-4 November 2010. 


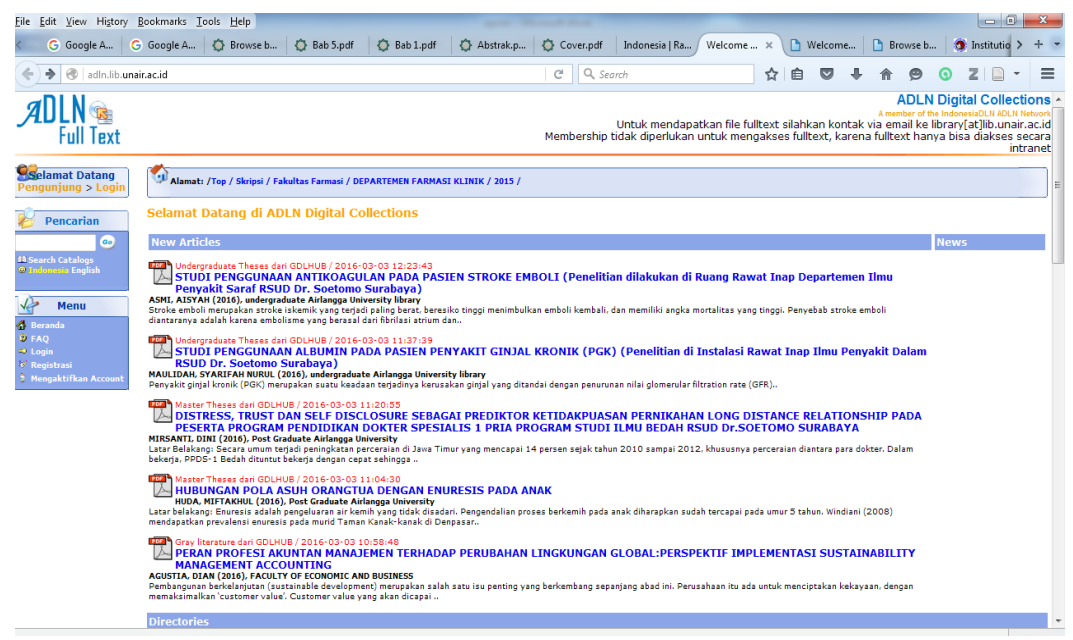

Gambar 2. Interface GDL

\section{c. DSpace}

DSpace adalah perangkat lunak sesuai untuk keperluan akademis, organisasi non-profit maupun kepentingan organisasi komersial yang membangun repository. Sebuah aplikasi opensorces yang cukup lengkap dan memungkinkan untuk dimodifikasi sesuai dengan kebutuhan lembaga, mampu mengakomodir seluruh jenis konten digital termasuk teks, gambar, video, mpegs, dan data sets sebagaimana dijelaskan dalam website DSpace (http://dspace. org) "DSpace is the software of choice for academic, non-profit, and commercial organizations building open digital repositories. It is free and easy to install "out of the box" and completely customizable to fit the needs of any organization. DSpace preserves and enables easy and open access to all types of digital content including text, images, moving images, mpegs and data sets. And with an ever-growing community of developers, committed to continuously expanding and improving the software, each DSpace installation benefits from the next. ${ }^{10}$

Beberapa perpustakaan yang menggunakan aplikasi DSpace ini adalah Perpustakaan UIN Syarif Hidayatullah Jakarta, Universitas Hasanuddin Makasar, Universtas Jember, Universitas

${ }^{10}$ http://dspace.org, diakses 15 Februari 2016. 
kresten Satya Wacana. Selengkapnya data perpustakaan digital yang menggunakan ketiga aplikasi ini sebagaimana tabel pada sub tema berikutnya. Berikut adalah tampilan (interface) Dspace. Sumber gambar: http://adlnlibunair.ac.id ${ }^{11}$

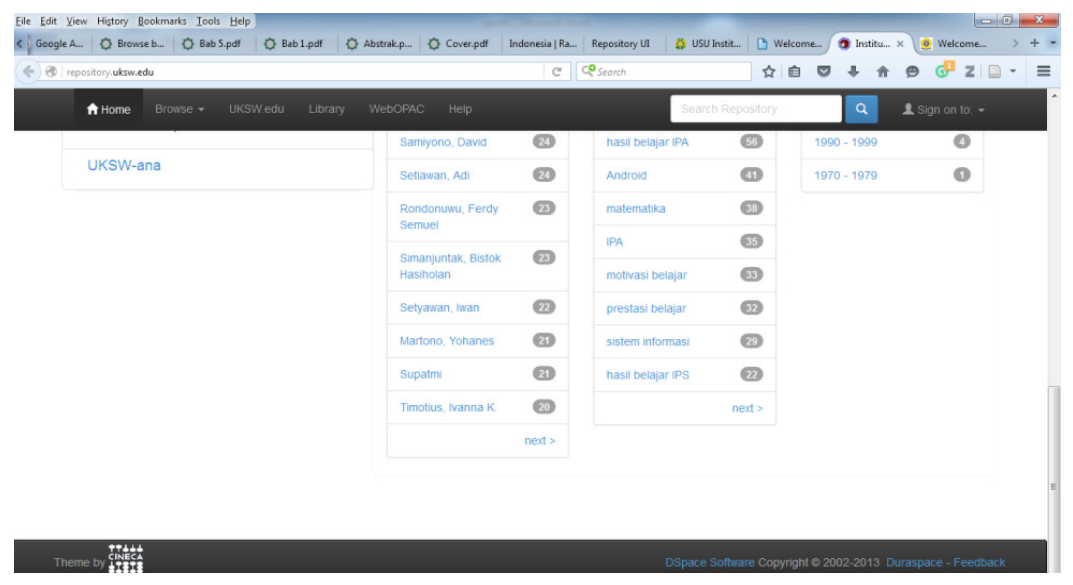

Gambar 3. Interface Dspace

\section{Pengguna E-prints di Indonesia}

Dalam kurun waktu beberapa tahun terakhir perpustakaan perguruan tinggi di Indonesia mulai memberikan perhatian serius terhadap pengembangan repository masing-masing. Terlebih lagi dengan adanya trend peringkat universitas (webometrics) yang banyak dipengaruhi oleh peran repository. Ada pendapat yang berkembang bahwa penggunaan aplikasi (software) untuk pengelolaan repository turut mempengaruhi capaian peringkat tersebut, sementara lembaga pengevaluasi peringkat webometrics repository memiliki kreteria penilaian yang cukup jelas. Salah satu website yang melakukan evaluasi dan membuat peringkat webometrics adalah http://repositories.webometrics.info/ yang merelase peringkat repository dunia setiap 2 (dua) kali setahun pada bulan Januari dan Juli. Perpustakaan perguruan tinggi yang menggunakan Eprints untuk mengelola repositornya, menduduki peringkat yang cukup baik dalam webometrics.

${ }^{11}$ http://adln.lib.unair.ac.id/, diakses 15 Februari 2016. 
Saat ini eprints banyak digunakan oleh perguruan tinggi di Indonesia dan bahkan Asia Tenggara. Kesimpulan sementara sebagaimana disampaikan purwoko dalam "Eprints vs DSpace" tahun 2015 bahwa dari segi kuantitas penggunanya, Eprints unggul dalam jumlah pengguna di Indonesia dan Asia Tenggara meskipun di beberapa negara di Asia Tenggara, DSPace lebih dominan. Namun pada level Asia, Eropa, Afrika dan dunia, maka DSpace menempati peringkat pertama. ${ }^{12}$ Data selengkapnya untuk pengguna eprints di Indonesia berdasarkan peringkat webometrics dapat dilihat pada tabel di bawah ini.

${ }^{12}$ Purwoko, «Eprints vs DSpace», 2015. 


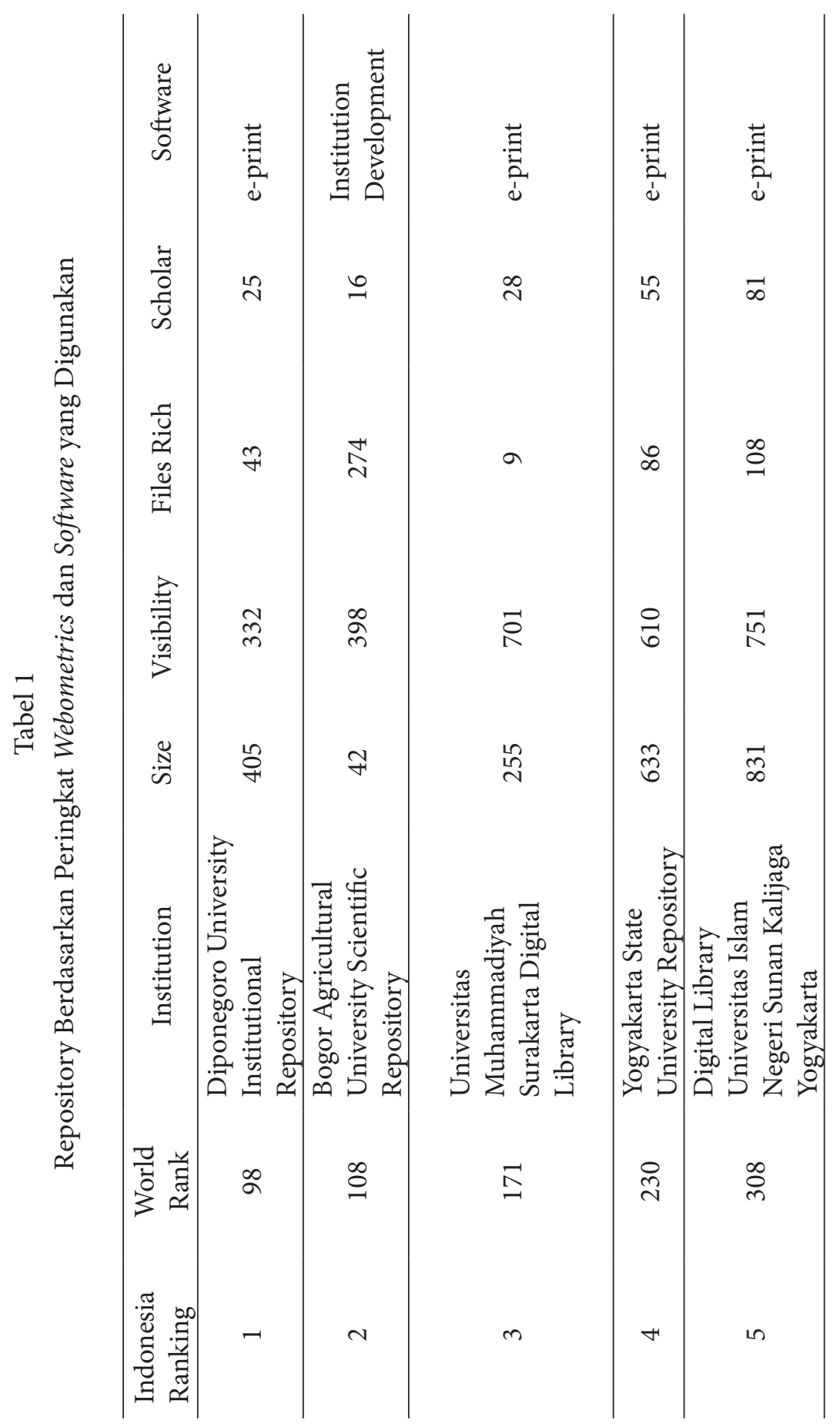




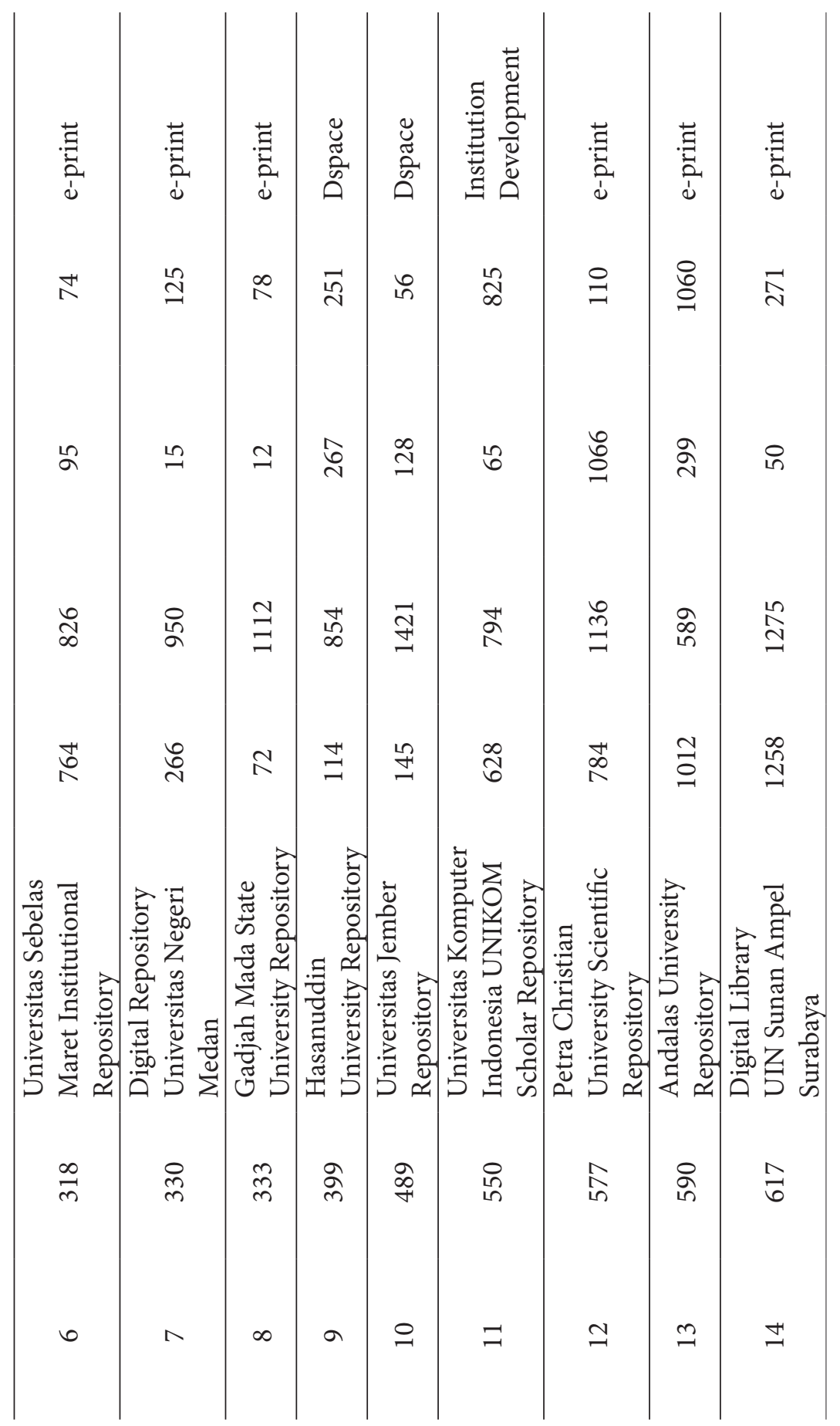




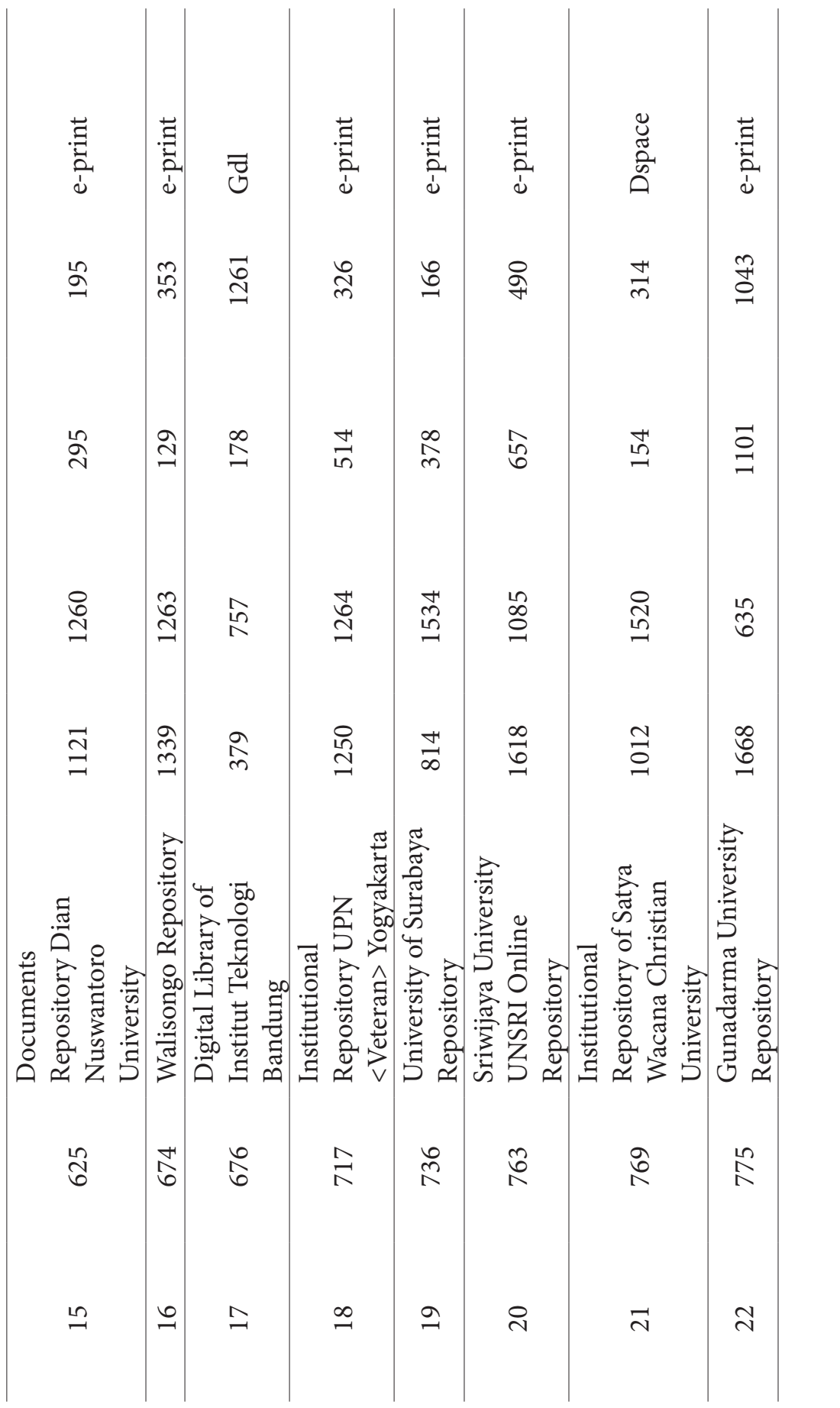




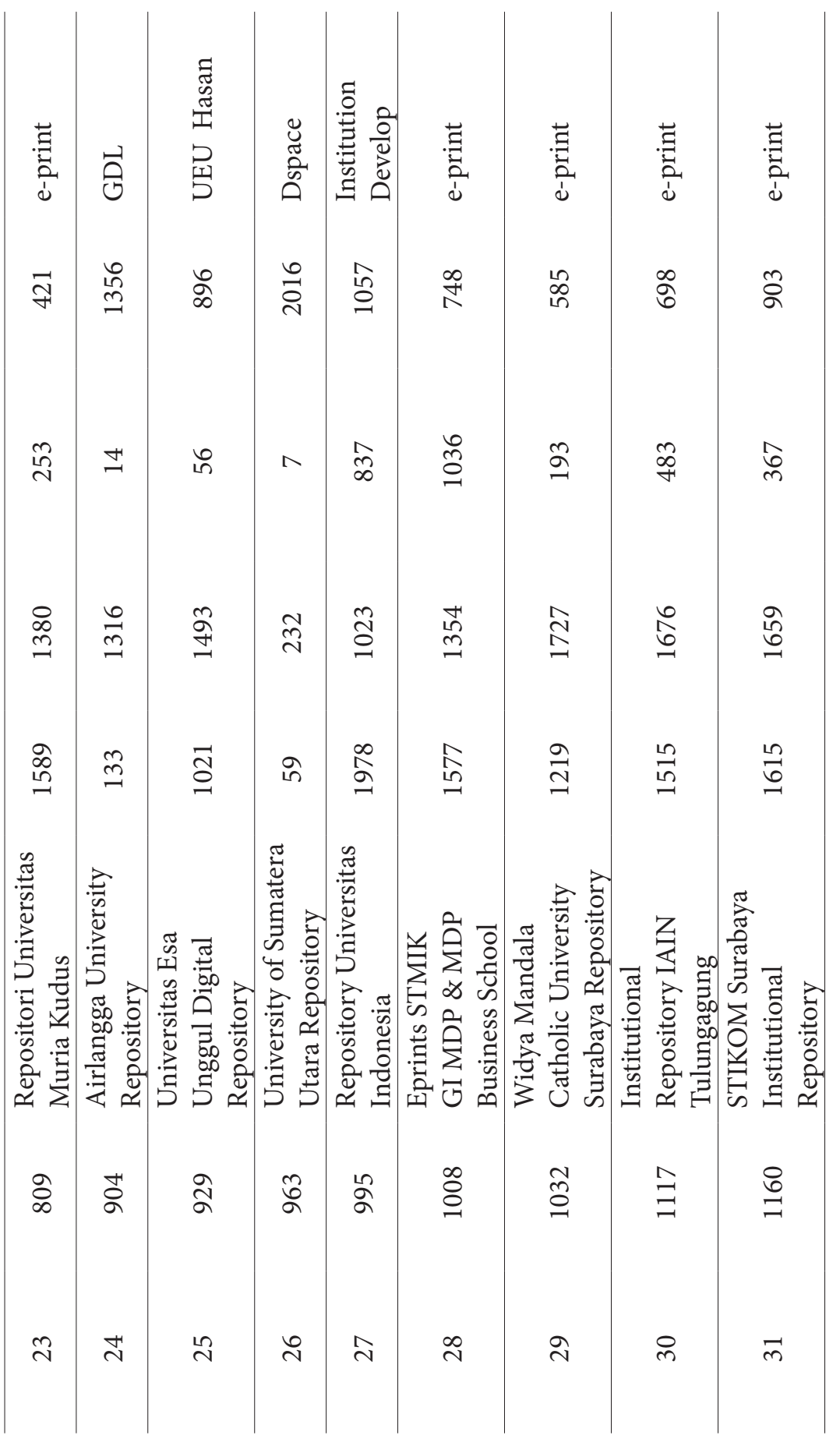




\begin{tabular}{|c|c|c|c|c|c|c|c|}
\hline 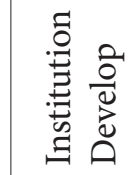 & $\begin{array}{l}\stackrel{\vec{\Xi}}{a} \\
\frac{a}{d}\end{array}$ & 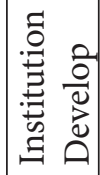 & 节 & $\begin{array}{l}\ddot{U} \\
\tilde{\Xi} \\
\stackrel{0}{0}\end{array}$ & 节 & $\begin{array}{l}\ddot{\tilde{z}} \\
\stackrel{\tilde{n}}{0} \\
\stackrel{\tilde{D}}{ }\end{array}$ & 节 \\
\hline $\begin{array}{l}0 \\
\stackrel{0}{\circ}\end{array}$ & ڤ్రి & $\stackrel{0}{n}$ & $\begin{array}{l}0 \\
\stackrel{-}{\circ}\end{array}$ & $\begin{array}{l}0 \\
\stackrel{\sim}{\circ}\end{array}$ & $\stackrel{\text { mे }}{\rightarrow}$ & $\begin{array}{l}0 \\
\stackrel{\sim}{0}\end{array}$ & 흥 \\
\hline 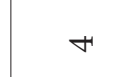 & ๖ి & $n$ & $\triangle$ & $\stackrel{\circ}{\stackrel{\sim}{\sim}}$ & $\stackrel{\sqrt{n}}{n}$ & $\vec{\infty}$ & $\begin{array}{l}\infty \\
\infty \\
0\end{array}$ \\
\hline in & ิㅡ & ஸి & 요 & હે & $\stackrel{\infty}{\Omega}$ & $\begin{array}{l}\infty \\
\stackrel{1}{=} \\
=\end{array}$ & ్ํ \\
\hline 후 & 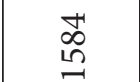 & $\stackrel{\infty}{\infty}$ & $\frac{\sim}{\sigma}$ & ) & مิ & م & $\begin{array}{l}n \\
\hat{\sigma}\end{array}$ \\
\hline 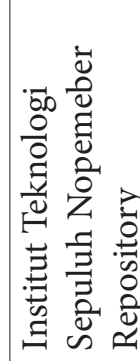 & 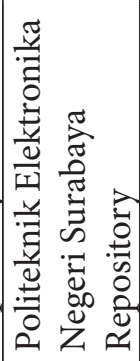 & 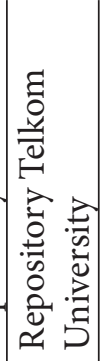 & 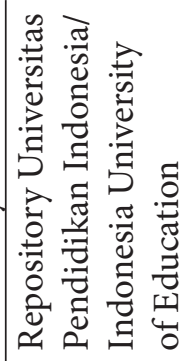 & 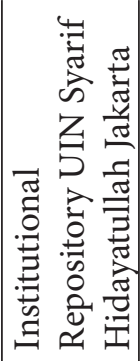 & 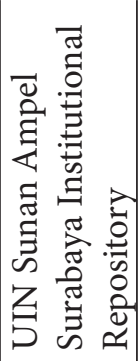 & 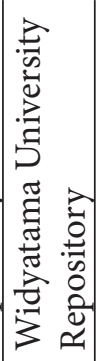 & 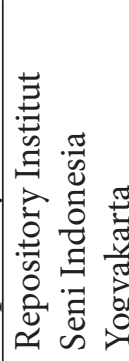 \\
\hline 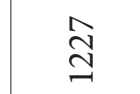 & 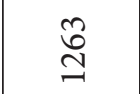 & $\stackrel{n}{n}$ & Ð & $\begin{array}{l}10 \\
10 \\
10 \\
-1\end{array}$ & 点 & 옹 & $\underset{\sigma}{\sigma}$ \\
\hline n & $m$ & $\vec{m}$ & $m$ & r & $\hat{n}$ & $\stackrel{\infty}{m}$ & m \\
\hline 238 & & & & & & & \\
\hline
\end{tabular}




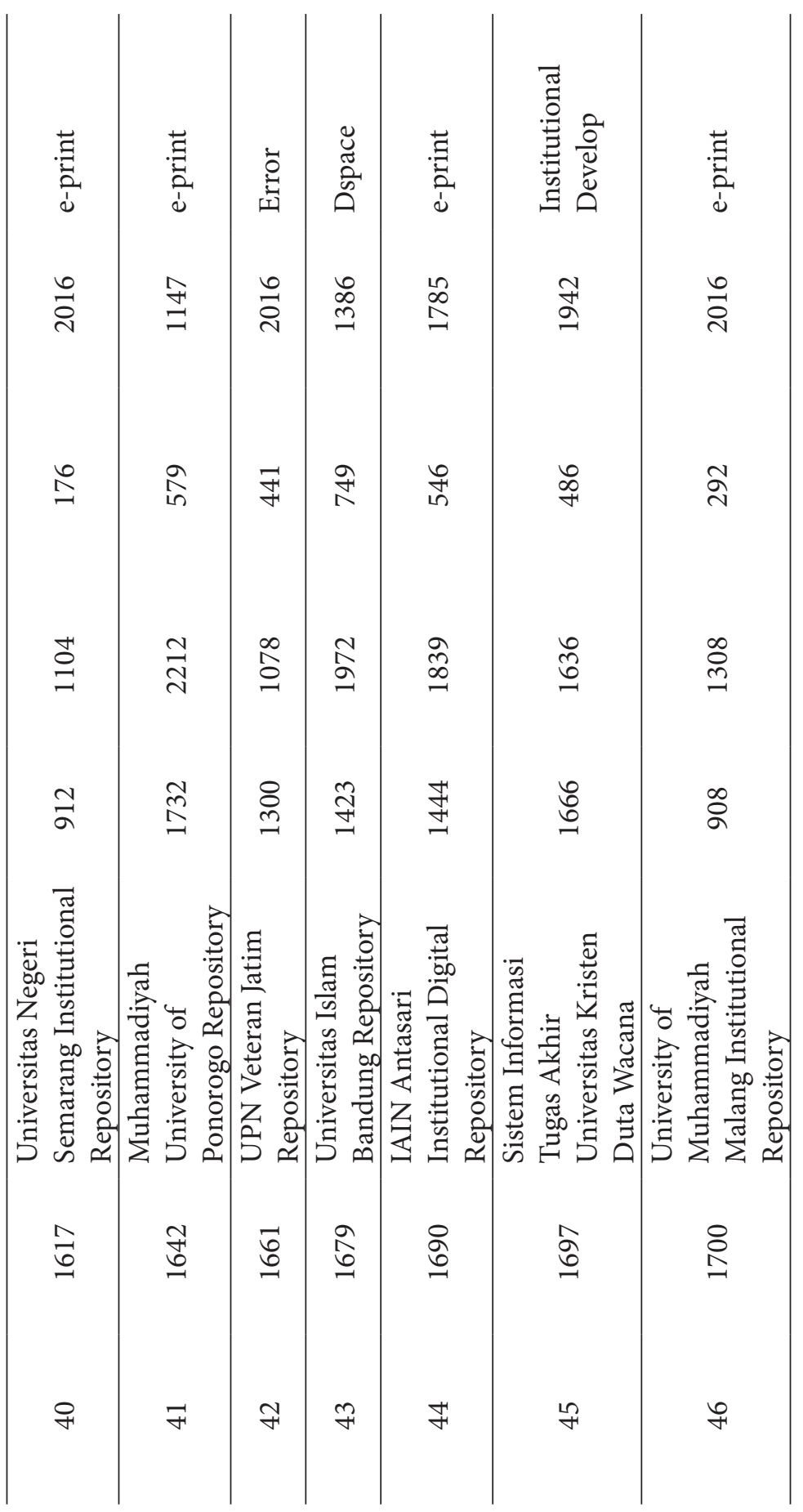




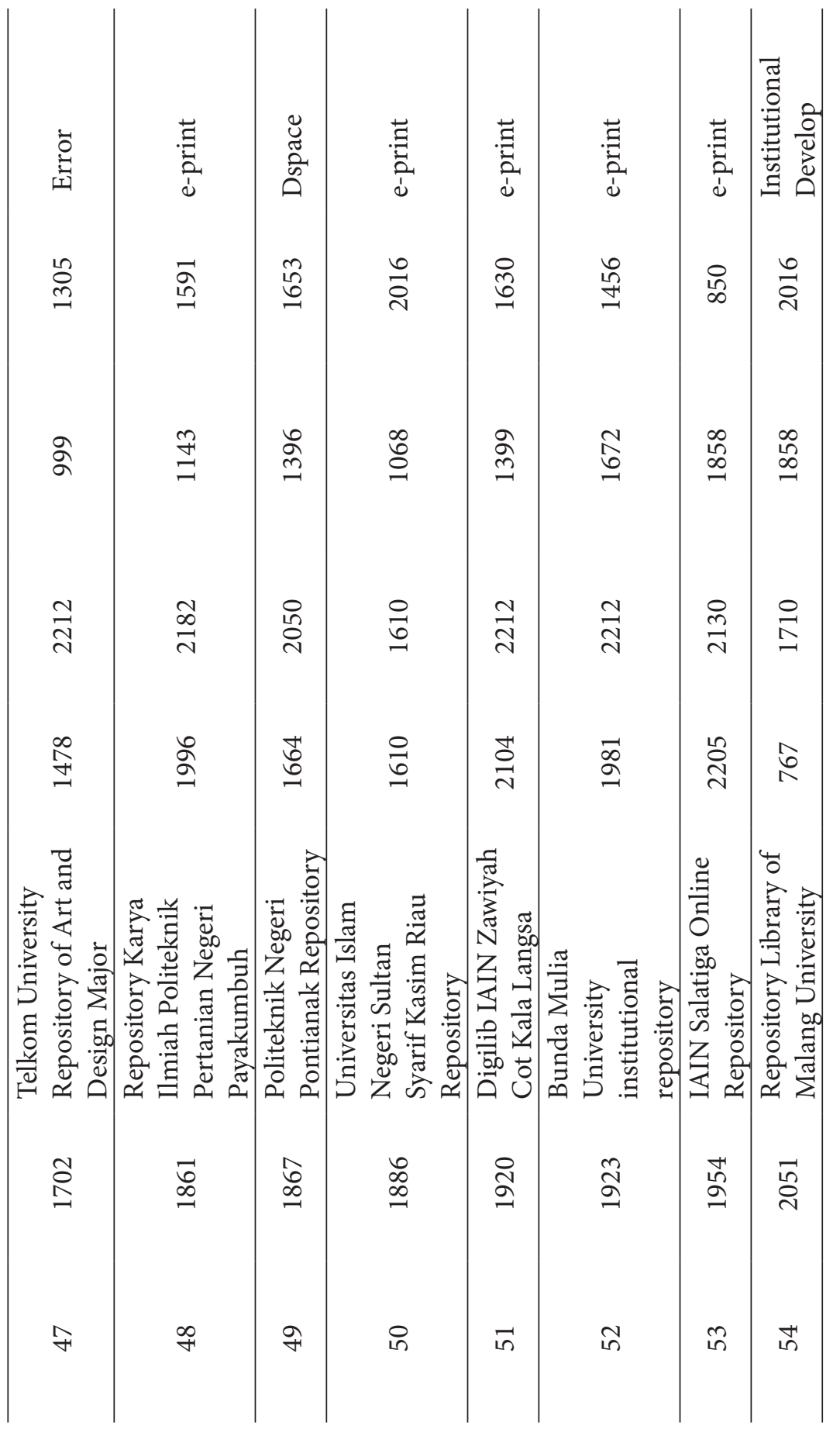




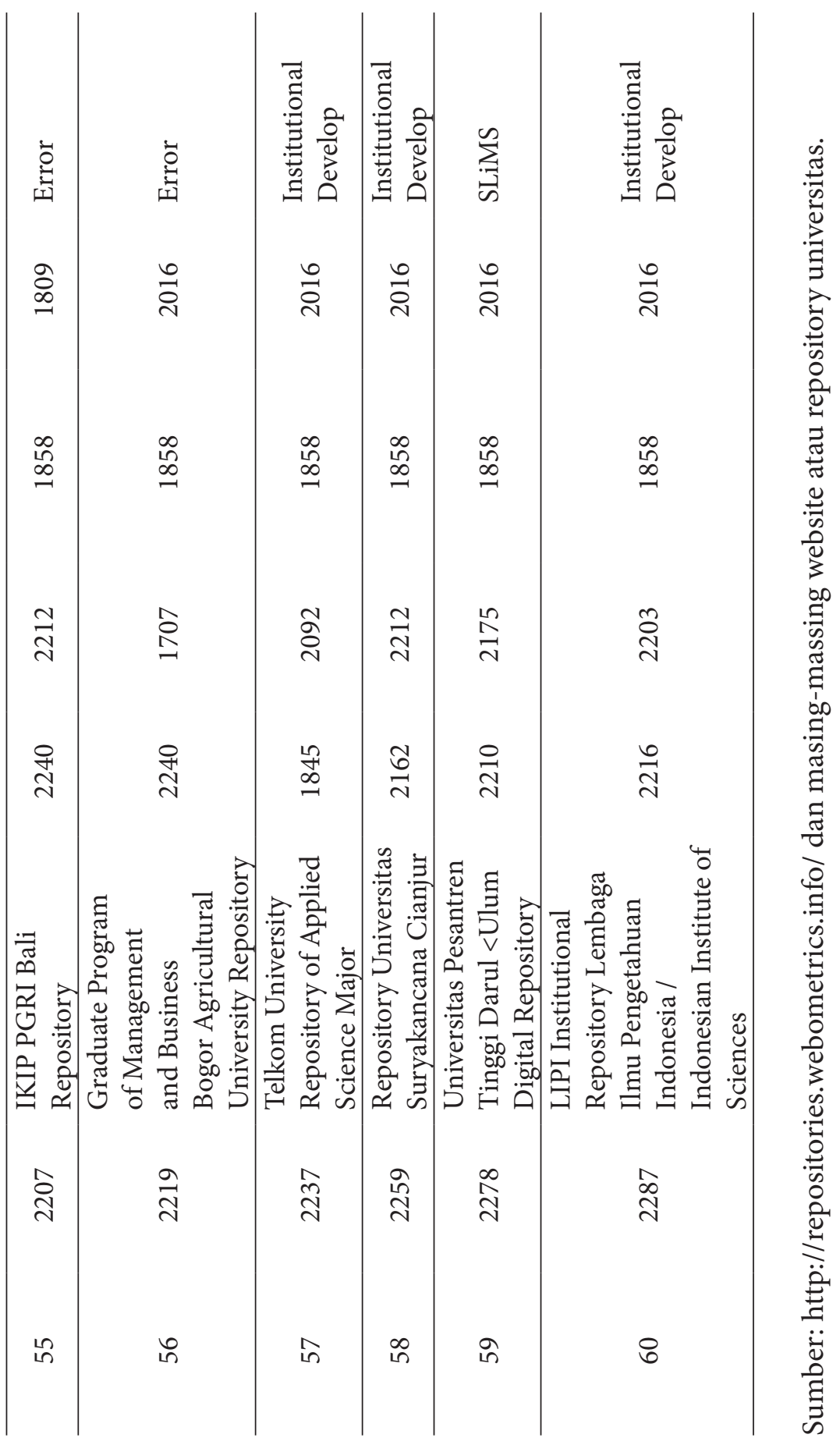


Tabel tersebut memberikan kita informasi bahwa dari 60 (enam puluh) repository peringkat teratas webometrics repository perguruan tinggi se-Indonesia, Eprints mendominasi penggunaan software yang dipakai. Pada posisi ke-dua DSpace (meskipun tidak bisa mengalahkan aplikasi hasil pengembangan institusi dan hanya 2 (dua) repository yang masih menggunakan aplikasi Ganesha Digital Library (DGL). Lebih jelasnya perbandingan antara aplikasi-aplikasi tersebut dapat dilihat pada tabel berikut.

Tabel 2

Perbandingan Jumlah Pengguna Aplikasi Eprint, Dspace, dan GDL Vesrsi Webometrics di Indonesia

\begin{tabular}{clcc}
\hline No. & \multicolumn{1}{c}{ Aplikasi/Software } & Jumlah Pengguna & $\%$ \\
\hline 1 & Eprints & 34 & $57 \%$ \\
\hline 2 & Dspace & 8 & $13 \%$ \\
\hline 3 & GDL & 1 & $0,4 \%$ \\
\hline 4 & Institutional Development & 10 & $17 \%$ \\
\hline
\end{tabular}

Dari 60 (enam puluh) responden repository perguruan tinggi di Indonesia yang berada pada peringkat teratas webometric versi http://repositories.webometrics.info, Eprints unggul 57\% dibanding Dspace yang hanya mencapai $13 \%$ pengguna dan (Ganesha Digital Library) GDL bahkan hanya dipakai 1 (satu) repository perguruan tinggi atau sekitar $0,2 \%$.

Peringkat webometrics untuk repository ini menjadi trend yang cukup menarik perhatian pengelola perpustakaan perguruan tinggi di Indonesia termasuk perguruan tinggi Islam di bawah Kementerian Agama RI. Ada 15 (lima belas) repository perguruan tinggi Islam di bawah pembinaan Kementerian Agama RI yang masuk dalam 60 (enam puluh) peringkat teratas, bahkan Universitas Muhammadiyah Surakarta pada posisi ke 3 (tiga) atau posisi ke-171 dunia, juga UIN Sunan Kalijaga Yogyakarta berhasil menduduki peringkat ke 5 (lima) atau peringkat ke-308 dunia. Selengkapnya perguruan tinggi Islam tersebut dapat dilihat pada tabel di bawah ini. 
Tabel 3

Perguruan Tinggi Islam di Indonesia yang Masuk 60 besar peringkat Webometrics Repository

\begin{tabular}{ccl}
\hline $\begin{array}{c}\text { Indonesia } \\
\text { Rank }\end{array}$ & World Rank & \multicolumn{1}{c}{ Institution } \\
\hline 3 & 171 & $\begin{array}{l}\text { Universitas Muhammadiyah Surakarta } \\
\text { Digital Library }\end{array}$ \\
\hline 5 & 308 & $\begin{array}{l}\text { Digital Library Universitas Islam Negeri } \\
\text { Sunan Kalijaga Yogyakarta }\end{array}$ \\
\hline 14 & 617 & $\begin{array}{l}\text { Digital Library UIN Sunan Ampel } \\
\text { Surabaya }\end{array}$ \\
\hline 16 & 674 & Walisongo Repository \\
\hline 30 & 1117 & $\begin{array}{l}\text { Institutional Repository IAIN } \\
\text { Tulungagung }\end{array}$ \\
\hline 36 & 1555 & $\begin{array}{l}\text { Institutional Repository UIN Syarif } \\
\text { Hidayatullah Jakarta }\end{array}$ \\
\hline 37 & 1574 & $\begin{array}{l}\text { UIN Sunan Ampel Surabaya } \\
\text { Institutional Repository }\end{array}$ \\
\hline 41 & 1642 & $\begin{array}{l}\text { Muhammadiyah University of Ponorogo } \\
\text { Repository }\end{array}$ \\
\hline 43 & 1679 & Universitas Islam Bandung Repository \\
\hline 44 & 1690 & $\begin{array}{l}\text { IAIN Antasari Institutional Digital } \\
\text { Repository }\end{array}$ \\
\hline 56 & 1700 & $\begin{array}{l}\text { University of Muhammadiyah Malang } \\
\text { Institutional Repository }\end{array}$ \\
\hline 50 & 1886 & $\begin{array}{l}\text { Universitas Islam Negeri Sultan Syarif } \\
\text { Kasim Riau Repository }\end{array}$ \\
\hline 51 & 1920 & $\begin{array}{l}\text { Digilib IAIN Zawiyah Cot Kala Langsa } \\
\text { IAIN Salatiga Online Repository }\end{array}$ \\
\hline 1954 & 2278 & $\begin{array}{l}\text { Universitas Pesantren Tinggi Darul } \\
<\text { Ulum Digital Repository }\end{array}$ \\
\hline
\end{tabular}

Dari data pada tabel di atas, dapat dilihat bahwa Repository Perguruan tinggi Islam di bawah bimbingan Kementerian Agama RI memiliki peringkat yang cukup signifikan di antara perguruan tinggi lainnya di Indonesia. Sebesar $25 \%$ dari responden merupakan repository perguruan tinggi Islam. Dari 15 (lima belas) repository tersebut, 13 (tiga belas) di antaranya menggunakan Eprints, 2 
(dua) menggunakan Dspace, dan 1 (satu) repository menggunakan SLiMS (Senayan Library and Information Systems).

\section{Simpulan}

Strategi pengembangan perpustakaan perguruan tinggi haruslah memperhatikan visi dan misi lembaga induknya. Tugas Tridharma Peguruan tinggi juga menjadi arah dan tujuan perpustakaan. Mengantarkan perguruan tinggi menjadi Universitas yang unggul dan kompetitif terutama dalam bidang penelitian menjadi strategi prioritas perpustakaan. Mengelola Institutional Repository merupakan salah satu strategi untuk meraih tujuan tersebut. Pengembangan Institutional Repository pada perguruan tinggi di Indonesia didominasi oleh penggunaan aplikasi Eprints. Dengan software Opensources ini telah terbukti banyak memberikan manfaat, baik dari sisi kemudahan akses maupun peningkatan peringkat webometrics. Lebih dari 50\% repository yang masuk pada peringkat 60 teratas webometrics, menggunakan Eprints. Dspace merupakan aplikasi terbanyak kedua yang digunakan di Indonesia. Beberapa perguruan tinggi pengguna Eprints di Indonesia, sebelumnya menggunakan aplikasi karya anak bangsa, yaitu (Ganesha Digital Library) GDL. Namun karna sudah tidak dikembangkan lagi maka mereka beralih ke Eprint. Sebuah aplikasi pengelola koleksi digital harus terus dikembangkan dan di update sehingga dapat terus beradaptasi dengan perkembangan zaman dan teknologi informasi. 


\section{DAFTAR PUSTAKA}

Arianto, Solihin. "Modul Instalasi Eprint 3 Pada Ubuntu Matakulian Perpustakaan Digital", Prodi Ilmu Perpustkaan Fakultas Adab dan Ilmu Budaya UIN Sunan Kalijaga Yogyakarta, 2012.

Fuadi, Miftakhul Yazid. "Evaluasi Kualitas Perangkat Lunak Eprints untuk Pengelolaan Perpustakaan Digital”, 2013. http://digilib.uin-suka.ac.id/9158/2/BAB\%20I,\%20V,\%20 DAFTAR\%20PUSTAKA.pdf.

Hasan, Nur. "Strategi Membangun dan Mengelola Institutional Repository pada Lingkup Perguruan Tinggi”, Makalah Konferensi Perpustakaan Digital Indonesia ke-3 di Bandung, 2-4 November 2010.

Laila, Azizah. "GDL (Ganesha Digital Library Versi 4.2", azizahlaila45, June 13, 2013. https://azizahlaila45. wordpress.com/2013/06/13/gdl-ganesha-digital-libraryversi-42/.

Lynch, Clifford A. "Institutional Repositories: Ess Ential Infrastructure for Scholarship in the Digital Age”, 2013. http://www:arl.org/bm doc/br226ir.pdf.

Pendit, Putu Laxman. Perpustakaan Digital dari A sampai Z. Jakarta:

Cita Karyakarsa Mandiri, 2008.

Purwoko. “Eprints vs DSpace”, 2015, diakses 16 Februari 2016.

Yanto. "Pengelolaan Institutioal Repository Perpustakaan Perguruan Tinggi: Studi Kasus di Perpustakaan UIN Sunan Kalijaga Yogyakarta”, Tesis, Program Pascasarjana Program Studi Interdiciplinary Islamic Studies UIN Sunan Kalijaga Yogyakarta, 2013. Diambil dari: http://digilib.uinsuka.ac.id/12296/1/BAB\%20I,\%20V,\%20DAFTAR\%20 PUSTAKA.pdf, 20 Februari 2016.

http://repositories.webometrics.info/ Akses tanggal 13 Pebruari 2016.

http://eprints.org Akses tanggal 13 Pebruari 2016. http://_dspace.org Akses tanggal 13 Pebruari 2016. 
http://eprints.undip.ac.id/ Akses tanggal 13 Pebruari 2016. http://repository.ipb.ac.id/ Akses tanggal 13 Pebruari 2016. http://eprints.ums.ac.id/ Akses tanggal 18 Pebruari 2016. http://eprints.uny.ac.id/ Akses tanggal 18 Pebruari 2016. http://digilib.uin-suka.ac.id/ Akses tanggal 18 Pebruari 2016. http://eprints.uns.ac.id/ Akses tanggal 18 Pebruari 2016. http://digilib.unimed.ac.id/ Akses tanggal 19 Pebruari 2016. http://repository.ugm.ac.id/ Akses tanggal 19 Pebruari 2016. http://repository.unhas.ac.id/ Akses tanggal 19 Pebruari 2016. http://repository.unej.ac.id/ Akses tanggal 19 Pebruari 2016. http://repository.unikom.ac.id/ Akses tanggal 19 Pebruari 2016. http://repository.petra.ac.id/ Akses tanggal 19 Pebruari 2016. http://repository.unand.ac.id/ Akses tanggal 20 Pebruari 2016. http://digilib.uinsby.ac.id/ Akses tanggal 20 Pebruari 2016. http://eprints.dinus.ac.id/ Akses tanggal 20 Pebruari 2016. http://eprints.walisongo.ac.id/ Akses tanggal 20 Pebruari 2016. http://digilib.itb.ac.id/ Akses tanggal 20 Pebruari 2016. http://repository.upnyk.ac.id/ Akses tanggal 20 Pebruari 2016. http://repository.ubaya.ac.id/ Akses tanggal 20 Pebruari 2016. http://eprints.unsri.ac.id/ Akses tanggal 19 Pebruari 2016. http://repository.uksw.edu/ Akses tanggal 19 Pebruari 2016. http://repository.gunadarma.ac.id/ Akses tanggal 19 Pebruari 2016.

http://eprints.umk.ac.id/ Akses tanggal 19 Pebruari 2016. http://digilib.esaunggul.ac.id/ Akses tanggal 19 Pebruari 2016. http://repository.usu.ac.id/ Akses tanggal 19 Pebruari 2016. http://repository.ui.ac.id/ Akses tanggal 19 Pebruari 2016. http://eprints.mdp.ac.id/ Akses tanggal 19 Pebruari 2016. http://repository.wima.ac.id/ Akses tanggal 19 Pebruari 2016. http://repo.iain-tulungagung.ac.id/ Akses tanggal 19 Pebruari 2016.

http://sir.stikom.edu/ Akses tanggal 19 Pebruari 2016. http://repo.pens.ac.id/ Akses tanggal 19 Pebruari 2016. 
https://repository.telkomuniversity.ac.id/ Akses tanggal 19 Pebruari 2016.

http://repo.pens.ac.id/ Akses tanggal 19 Pebruari 2016.

http://repository.upi.edu/ Akses tanggal 19 Pebruari 2016.

http://repository.uinjkt.ac.id/dspace/ Akses tanggal 19 Pebruari 2016.

http://eprints.uinsby.ac.id/ Akses tanggal 19 Pebruari 2016.

http://repository.widyatama.ac.id/ Akses tanggal 19 Pebruari 2016.

http://digilib.isi.ac.id/ Akses tanggal 20 Pebruari 2016.

http://eprints.umpo.ac.id/ Akses tanggal 20 Pebruari 2016.

http://lib.unnes.ac.id/ Akses tanggal 20 Pebruari 2016.

http://idr.iain-antasari.ac.id/ Akses tanggal 20 Pebruari 2016.

http://repository.unisba.ac.id/ Akses tanggal 20 Pebruari 2016.

http://sinta.ukdw.ac.id/sinta/ Akses tanggal 20 Pebruari 2016.

http://repository.unsur.ac.id/ Akses tanggal 20 Pebruari 2016. 
Halaman ini bukan sengaja dikosongkan 